\title{
Human Abzymes with Amylolytic Activity
}

\author{
澱粉分解活性をもつヒトアブザイム
}

\author{
Kulminskaya, Anna A. ${ }^{1}$; Saveliev, Andrew N. ${ }^{2}$; and Neustroev, Kirill N. ${ }^{1 *}$ \\ ${ }^{1}$ Molecular and Radiation Biophysics Division, Petersburg Nuclear Physics Institute of Russian Academy of Sciences, \\ Gatchina, Russia \\ ${ }^{2}$ Biophysics Department, St.-Petersburg Technical University, St. Petersburg, Russia \\ * To whom correspondence should be addressed: Petersburg Nuclear Physics Institute, \\ Russian Academy of Science, Gatchina, St. Petersburg, 188300, Russia. \\ FAX: 7-81271-32303, E-mail: neustk@omrb.pnpi.spb.ru
}

Key Words: abzymes, amylolytic activity, autoimmune pothotogies

\begin{abstract}
Amylolytic abzymes are a new type of catalytically active human antibodies that have been found recently. Various immunoglobulins from the sera of patients with autoimmune diseases and human milk were found to possess amylolytic activity, which is expressed in their ability to hydrolyze $\alpha-(1,4)$ D-glucosyl linkages of maltooligosaccharides, starch, glycogen, and several artificial substrates. Pure IgM fractions isolated from several tens of analyzed patients with clinically definite diagnoses of multiple sclerosis (MS) and systemic lupus erythematosus (SLE) had approximately three orders of magnitude higher specific amylolytic activity than those for healthy donors. Average values for the specific amylolytic activity of IgGs and sIgAs from human milk were five times less than of IgMs from autoimmune patients. Strict criteria were used to prove that the amylolytic activity of abzymes was their intrinsic property and was not due to any enzyme contamination. Fab fragments derived from IgM and IgG fractions of human abzymes displayed the same level of amylolytic activity. Values for Michaelis constants $K_{\mathrm{M}}$ in the abzyme-mediated hydrolysis of different $\alpha$-Dmaltooligosaccharides and $\alpha$-D-maltooligosaccharides with chromogenic and fluorescent label on reducing end were in the range of 1-2 to $0.01 \mathrm{mM}$. Abzyme fractions from different donors demonstrated catalytic heterogeneity in Michaelis-Menten parameters and different modes of action in the hydrolysis of natural and artificial substrates. One part of amylolytic immunoglobulins exhibited exo-amylase action when others have also $\alpha$-glucosidase activity yielding glucose and capable of cleaving pnitrophenyl $\alpha$-D-glucopyranoside. Enzymatic properties of all tested amylolytic abzymes distinguished from those of putative human $\alpha$-amylases. None of the IgM, IgG, and sIgA samples investigated showed transglycosylating ability.
\end{abstract}

要 約

澱粉分解活性をもつアブザイムが酵素活性をもつヒト抗体 の新しいタイプとして最近発見された。自己免疫疾患患者の血 清やヒトの母乳にはマルトースオリゴサッカライド、澱粉、グ

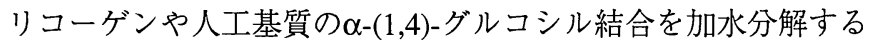
活性をもつさまざまな免疫グロブリンがあることが知られてい た。臨床的に多発性硬化症や全身性エリマトーデスであると診 断された数十人の患者の IgM 分画は健常者のものと比較して澱 粉分解の比活性が約千倍高い。ヒト母乳の $\operatorname{IgG}, \operatorname{IgA}$ の活性の平 均值は比活性にして自己免疫疾患患者の $\operatorname{IgM}$ の五分の一以下で あった。アブザイムの活性は抗体そのものがもつ性質であって 酵素の混入によるものではないことを証明するための厳密な実 験が扔こなわれてきた。アブザイムの $\operatorname{IgM}$ と IgG 分画を Fab フ ラグメントにしても同程度の活性を示した。還元末端に発色団 や蛍光標識をもつさまざまなマルトースオリゴサッカライドに 対するアブザイムによる分解活性の $K_{\mathrm{M}}$ は 1 2 $\mathrm{mM}$ から $0.01 \mathrm{mM}$ であった。異なるドナーからのアブザイムはミカエリスメンテ ン值の不均一性を示し天然基質や人工基質の分解様式にも差異 がみられた。あるものはエキソ型アミラーゼ活性を示し、また あるものはグルコースを遊離する $\alpha$ グルコシダーゼ活性を示し p-ニトロフェニル- $\alpha-\mathrm{D}-$ グルコピラノサイドを分解できた。調ベ られたすべての澱粉分解活性をもつアブザイムの酥素的性質は ヒトの $\alpha$-アミラーゼと異なっていた。IgM, IgG, $\operatorname{sg} A$ はいず れもトランスグリコシレーション活性を示さなかった。

\section{A. Introduction}

Antibodies (Abs) possessing enzymatic activities

\section{A. はじめに}

酵素活性をもつ抗体 (アブザイム) が存在することはよく知 
Trends in Glycoscience and Glycotechnology Vol.16 No.87 (January 2004) pp.17-31

(abzymes) are becoming a well-known phenomenon. The hypothesis of Jencks, that monoclonal antibodies directed against an analog of transition state of an enzymatic reaction can exhibit a catalytic function $(1,2)$, forms the basis for understanding abzyme production. Thus, raising monoclonal or polyclonal antibodies to chemically synthesized haptens, which imitate transition states, show the presence of catalytic activity. With this approach, more than a hundred types of catalytic, mainly hydrolytic, activities were obtained $(3,4)$. The method of immune response on transition state was also used for the creation of nonhydrolytic antibodies capable of catalyzing cationic cyclization (5), acyl-transfer reaction (6) and some others (7). Antibodiesenzymes were named 'abzymes' as an abbreviation between AntiBody and enZYME. Abzymes (Abzs) obtained by the abovementioned method have extremely high catalytic efficiency: rate accelerations for catalytic antibody-mediated transformations are up to $10^{6}$ higher than for un-catalyzed chemical reactions (8). In some cases, Abzs show higher stereospecificity than putative enzymes. This approach, i.e. immunization on various haptens, also enables obtaining new enzymatic activities, which do not have analogs in traditional enzymology (9).

Another successful method, the induction of anti-idiotypic antibodies, has been recently developed for the production of catalytically active antibodies. It is based on the production of secondary antibodies on antibodies initially elicited against the active center of the enzyme (10).

Several years ago, a phenomenon of in vivo generation of catalytic antibodies in the sera of humans was discovered. The first record on human catalytic IgGs isolated from the blood of patients with such autoimmune diseases as asthma and thyroiditis, reported their ability to hydrolyze peptides and proteins $(11,12)$. It was the first time that human catalytic autoantibodies were also called abzymes. Further, all antibodies exhibiting enzymatic properties were given this name. Nuclear acid nicking activity was next observed at human autoantibodies. Thus, the IgG fractions isolated from the blood of patients suffering from systemic lupus erythematosus (SLE) were found to manifest DNA-hydrolytic activity $(13,14)$. Further findings revealed that RNA-cleaving activity of immunoglobulins $\mathrm{G}$ and $\mathrm{M}$ correlates with a number of autoimmune pathologies, like multiple sclerosis (MS), SLE, Hashimoto's thyroiditis, polyarthritis, and rheumatoid arthritis (15-17). Noteworthy, healthy donors and patients suffering from influenza, pneumonia and tuberculosis do not exhibit essential level of RNA- and DNA-hydrolase activities of sera antibodies. However, both activities were found in $\mathrm{IgG}$ and $\operatorname{sg} \mathrm{A}$ fractions from human milk of healthy mothers (19).

The last catalytic activity that was detected in human autoantibodies was amylolytic. It appeared that human abzymes cleave off linkages both in different $\alpha$-D-maltooligosaccharides and glycogen or starch (20). Below, we will discuss the spread-
られた現象である。酵素反応の遷移状態の基質アナログに対す るモノクローナル抗体は触媒活性を示しうるという Jencks の仮 説はアブザイムの生成を理解する根拠となっている。すなわち 遷移状態を真似て化学的に合成されたハプテンに対してモノク ローナルおよびポリクローナル抗体を作成すると酵素活性がみ られる。この方法により百種類以上の触媒活性 (主に加水分解活 性) が得られた $(3 、 4)$ 。遷移状態に対する免疫応答の手法は加水 分解活性以外の活性、ポリエンの環化 (5)、アシル基転移 (6)、 その他 (7)、をもつ抗体の作成にも用いられた。酵素活性をもつ 酵素は抗体 AntiBody と酵素 enZYME の両方をあわせた略とし てアブザイム abzymes (Abzs) と名付けられた。上記の方法で得 られたアブザイムは非常に高い酵素活性をもち化学反応の速度 を $10^{6}$ 倍にも高める $(8)$ 。いくつかの例ではアブザイム は酵素 よりも高い立体特異性を示す。さまざまなハプテンによる免疫 を行うという手法により古典的酵素学でアナログがみつかって いない新しい酵素活性を得ることも可能である (9)。

酵素活性をもつ抗体を作成するためのよい方法として抗イ ディオタイプ抗体を作成するという方法が最近開発された。こ れは酵素の触媒部位に対する抗体に対する二次抗体を作成する ものである (10)。

数年前に in vivo でも触媒活性をもつ抗体が生成している現 象がヒト血清において発見された。最初の報告は喘息や甲状腺

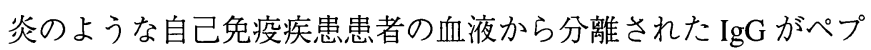
チドやタンパク質を加水分解する活性をもつというものであっ た(11、12)。またこれは酵素活性をもつヒトの自己抗体もアブザ イムと呼ばれた最初でもあった。酵素活性をもつすべての抗体 にこの名称が与えられるようになった。次に核酸にニックを入 れる活性をもつものが七ト自己抗体に見つかった。全身性エリ マトーデス (SLE) 患者の血液の IgG 分画に顕著な DNA 分解活 性があったのである (13、14)。引き続いて IgG, IgM の RNA 分 解活性がさまざまな自己免疫疾患、多発性硬化症 (MS), SLE, 八シモト甲状腺炎、リウマチ性関節炎(15-17)、と関連すること が明らかになった。特筆すべきことにインフルエンザ、肺炎、 結核の患者と健常者のどちらの血清にも RNA や DNA の分解 活性はないのに、健康な母親の母乳の IgG, sIgA には両方の分 解活性が発見された (19)。

ヒト自己抗体の触媒活性として最後に見つかったものが澱 粉分解活性である。ヒトのアブザイムには異なる $\alpha$-マルトース オリゴサッカライドとグリコーゲンや澱粉を分解する活性が見 
ing of human amylolytic abzymes and the specificity of their action.

\section{B. Amylolytic Abzymes: Where Were They Found ?}

All human antibodies with amylolytic activity are able to hydrolyze $\alpha 1,4$-glucosidic bonds both in polymeric substrates (starch, glycogen, amylose) and maltooligosaccharides with a degree of polymerization (d.p.) greater than 3. In the latter case, amylolytic Abzs yield maltose, maltotriose and maltotetraose as main products of the hydrolytic reactions similarly to $\alpha$-amylases (E.C. 3.2.1.1) from various sources $(21,22)$. Like traditional exo-amylases, fractions of human Abzs with amylolytic activity hydrolyze also well-known, commercially available substrate, 4-nitrophenyl 4,6- $O$-ethylidene- $\alpha$-D-maltoheptaoside (EPS), as well as $p$-nitrophenyl (PNP) $\alpha$-D-maltooligosaccharides or 4-methylumbelliferyl (MeUmb) $\alpha$-D-maltooligosaccharides (Fig. 1) $(23,24)$. A part of the tested samples showed $\alpha$-D-glucosidase (E.C.3.2.1.20) action and as such, were able to hydrolyze PNP $\alpha$-D-glucoside, maltose and maltotriose. Obviously, such amylolytic abzymes produce glucose along with short maltooligosaccharides in the hydrolysis of polymeric and oligomeric substrates. It is glucose that is a final product of the completed hydrolysis catalyzed by human amylolytic Abzs of such mode of action (Fig. 1).

Initially, amylolytic activity was shown in the IgG preparations isolated from the blood of pregnant women and several cancer patients (20). Then, similarly to nuclear acid hydrolyzing activity, amylolytic function was found in $\operatorname{IgG}$ and $\operatorname{sIgA}$ fractions of human milk $(23,24)$. Specific amylolytic activities*
いだされた (20)。以下にヒトの澱粉分解活性をもつアブザイム の分布と反応の特異性を述べたい。

B. 澱粉分解活性をもつアブザイム：どこで発見されたか？ すべての澱粉分解活性をもつヒト抗体は多糖類 (澱粉、グリ コーゲン、アミロース) 拉よび重合度 3 以上のマルトースオリゴ

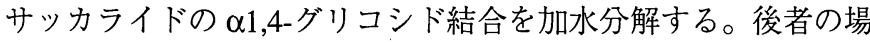
合アブザイムによる主な生成物はマルトース、マルトトリオー ス、マルトテトラオースであり、この点はさまざまな由来の $\alpha-$ アミラーゼ (E.C. 3.2.1.1) による生成物と同様である $(21 、 22) 。 エ$ キソーアミラーゼの場合のようにヒトアブザイムはよく知られ た市販の基質、4-ニトロフェニル 4,6-O-エチリデン $\alpha-D$-マルトへ プタサイド (EPS)、 $p$ ニトロフェニル - (PNP) $\alpha$-D-マルトースオリ ゴサッカライド、4-メチルウンベリフェル (MeUmb) $\alpha$-D-マルト オリゴサッカライドも分解する (図1) (23、24)。一部のアブザイム は $\alpha$-D-グリコシダーゼ (E.C.3.2.1.20) 活性をもち PNP $\alpha$-D-グル コサイド、マルトース、マルトトリオースを分解する。明らか に、そのような澱粉分解活性をもつアブザイムの生成物はマル トースオリゴサッカライドの他にグルコースを含んでいる。そ うしたアブザイムの反応が完全に進行した場合の最終産物はグ ルコースである。

最初に澱粉分解活性は妊娠女性やがん患者の血液の $\operatorname{IgG}$ 分 画にみいだされた $(20)$ 。そして核酸ニッキング活性と同様に、 ヒトの母乳の IgG, sIgA 分画に見つかった $(23 、 24)$ 。調べられた

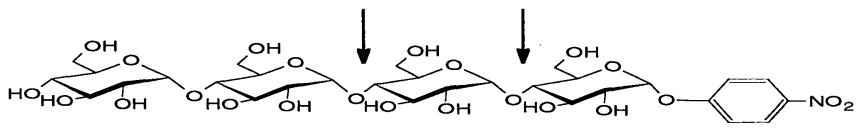

Exo-amylase-like Abz action
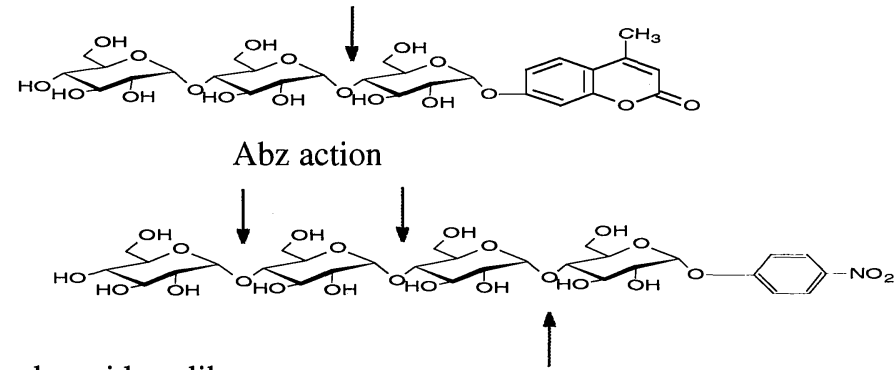

Exo-amylase/ $\alpha$-glucosidase-like

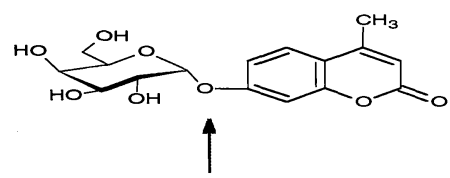

Fig. 1. Exo-amylolytic and $\alpha$-glucosidase activities of human abzymes.

\footnotetext{
* Here and therein, specific amylolytic activity was defined as an amount of Ig required for formation of $1 \mu$ mole of reducing sugar at $\mathrm{pH} 7.0,37^{\circ} \mathrm{C}$.
} 
of all 25 tested samples of immunoglobulins obtained from human milk were practically at the same level ranging in $0.15-$ $0.25 \mathrm{U} / \mathrm{mg}$ (Fig. 2). Samples of milk were taken from healthy human mothers $(19=35$ years old $)$ within the period from 1 week until 3 months of lactation. Higher values for the specific activity (about $1 \mathrm{U} / \mathrm{mg}$ ) were estimated for IgMs from autoimmune patients suffering from MS and SLE (Fig. 2). It should be noted that stable increased level of amylolytic activity correlates only with IgMs from MS and SLE patients while it is significantly lower (about 20-40 times) for a number of IgG fractions at the same pathologies. Moreover, activity heterogeneity for IgG samples from different donors is quite high (Fig. 3). As a control, IgG and IgM preparations from more than 50 patients not suffering from autoimmune diseases were assayed $(25,26)$. Absolutely in all cases, the level of the specific amylolytic ac-
25 検体のヒト母乳の免疫ブロブリンの活性 $(0.15 \sim 0.25 \mathrm{U} / \mathrm{mg})$ は 同程度であった (図2)。母乳は授乳開始 1 週間から 3 ケ月まで の健康な母親 (19 歳から 35 歳) から採取された。MS や SLEの 自己免疫疾患患者の IgM は高い比活性を示した (図2)。活性が 高いのは IgM であって、同じ患者の IgG の比活性は顕著に低 かった (20 から 40 分の 1)。さらに異なるドナーからの IgG サ

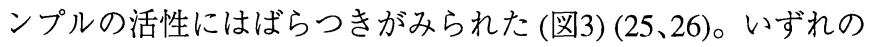
場合においても健常者からの IgG，IgM 分画の澱粉分解活性は 自己免疫疾患患者の場合の千分の一以下であった。アブザイム の澱粉分解活性は $\alpha$-アミラーゼや $\alpha$-グルコシダーゼそのものの

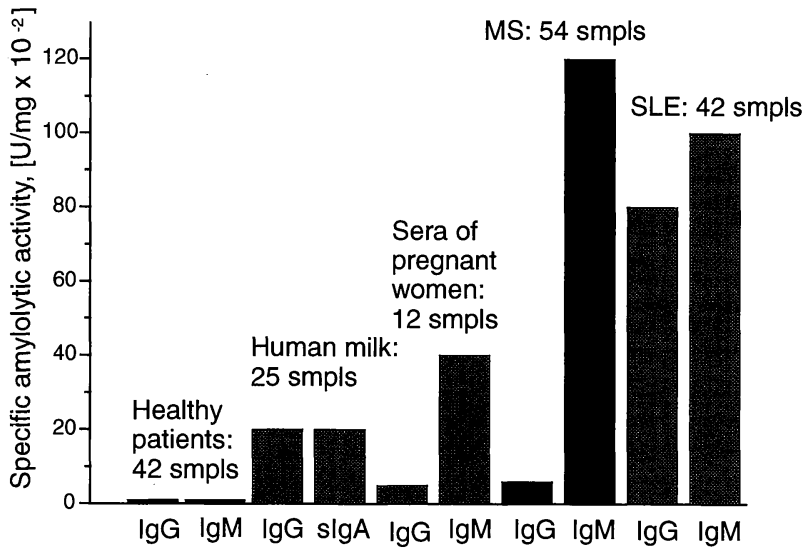

Fig. 2. Average specific amylolytic activity for different samples of human abzymes.

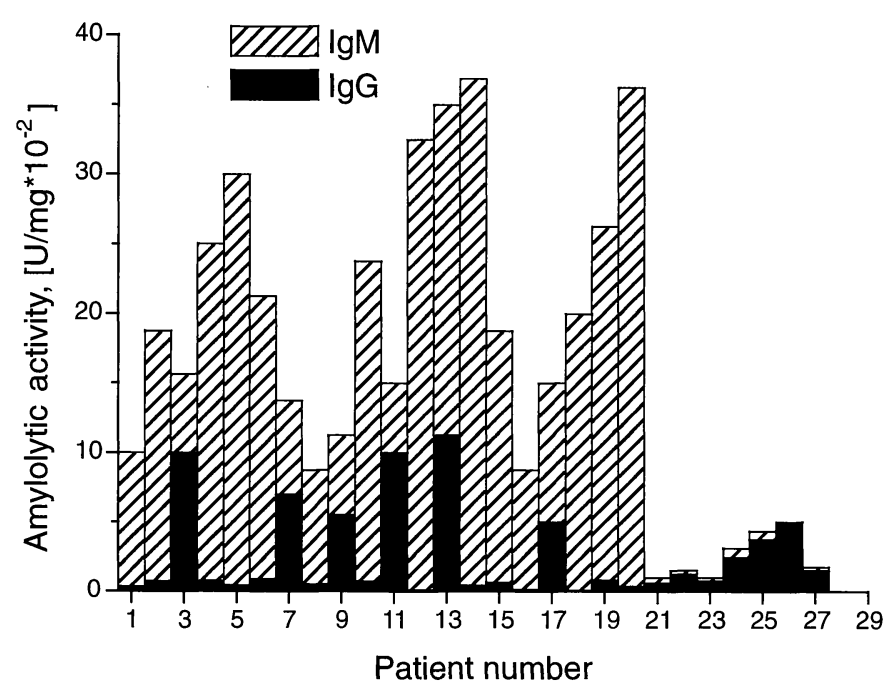

Fig. 3. A selective set of values for the specific $\alpha$-amylolytic activities of SLE abzymes in the hydrolysis of PNP maltohexaose. 
Trends in Glycoscience and Glycotechnology Vol.16 No.87 (January 2004) pp.17-31

tivity of Abzs isolated from healthy donors was three orders of magnitude lower than for autoimmune patients and was in the range from $0.05-2 \mathrm{U} / \mathrm{mg}$. It is not less than $10^{2}$ times lower than for traditional $\alpha$-amylases and $\alpha$-glucosidases. Similarly low, when compared with putative enzymes, specific activities were demonstrated for proteolytic and nuclear acid nicking abzymes. However, we should remember that we deal with polyclonal antibodies and only part of which can display enzymatic activity. It was reported that at direct immunization with appropriate hapten (active immunization approach) only $1 \%$ of total IgGs were catalytic catalyzing the hydrolysis of carbomate insectide (27). Therefore, we suppose that only $1 \%$ of catalytically active amylolytic antibodies can be observed in all investigated human Ig samples. This means that the specific activity of a catalytic fraction increases about 100 times and becomes of the same order as traditional $\alpha$-amylases $(21,22)$.

\section{How to Purify Amylolytic Abzymes Effectively and Prove $\alpha$-Amylase Activity of Autoantibodies ?}

Purification of human catalytic antibodies is a separate problem in abzymology. Indeed, specific enzymatic activity of antibodies is several orders of magnitude lower than for similar putative enzymes. It is conditioned, as mentioned above, by a low amount of catalytic antibodies in the total fraction of human Igs. Therefore, removal of even minor admixtures of traditional enzymes during purification is absolutely essential $(23,28)$.

Another point of issue that should be taken into consideration is the ability of Igs to form non-covalent complexes with various proteins and enzymes, which can be co-eluted with antibody fractions at chromatographic stages of purification (29). Methods of isolating human polyclonal catalytic antibodies both from blood and milk that have been developed include sulfate ammonium precipitation as a first step and two subsequent ionexchange chromatographies using also FPLC on a Mono Q column $(23,25)$. Then affinity chromatography or immobilized secondary antibodies produced against corresponding Igs are usually used. The final, fifth, step is a gel-permeation chromatography on a Superose 12 or Sephacryl S-200 column equilibrated with $1 \mathrm{M}$ of guanidine chloride. This stage was added to the purification procedure in order to separate immunoglobulins from possible contamination from non-covalently bound enzymes and proteins. To purify IgGs with DNA-nicking activity, affinity chromatography on a column coupled with DNA was used at this stage (30). After all purification stages, Ig fractions are electroforetically homogenous $(23,25)$. However, homogeneity by SDS electrophoresis is an insufficient criterion to justify the presence of enzymatic activity in Ig fractions in view, first of all, of low specific activity of human Abzs. Several additional rigid criteria have been developed earlier to show the phenomenon of human natural proteolytic and DNA-nicking abzymes $(12,14)$ and should be used each time when natural
活性の百分の一よりは高い。同様に本来の酵素と比較すれば低 いながらもタンパク分解活性と核酸ニッキング活性があること も明らかにされている。今議論しているのはポリクローナル抗 体であり、活性をもつものはほんの一部にすぎない。ハプテン を直接免疫した場合に得られる酵素活性をもつ IgG は全体の 1 \%という報告がある (27)。そこで今まで調べられたヒトの免疫 グロブリンサンプルにおいても活性をもつものは $1 \%$ であると 仮定すると、比活性は 100 倍になり本来の酵素と遜色ない值に なる $(21 、 22)$ 。

C. 澱粉分解活性をもつアブザイムはどのように精製され、活性 をもつことが証明されたのか？

触媒活性をもった抗体を精製するというのはアブザイム研 究におけるひとつの課題である。抗体の酵素活性は本来の酵素 の活性よりも比活性にして数行低い。これは抗体の中で活性を もつものはごくわずかであることに起因する。そこで精製段階 において本来の酵素を取り除くことが決定的に重要なことにな る $(23,28)$ 。

もうひとつ考慮しなければならないことは抗体がさまざま なタンパク質や酵素と非共有結合して、それらの物質が精製段 階のクロマトグラフィーで抗体と共に溶出されてくることであ る (29)。血液と母乳から酵素活性をもつポリクローナル抗体を 分離するために、まず初めに硫安沈殿をしてから FPLC の MonoQ カラムを用いた 2 段階のイオン交換カラムクロマトグラ フィーが行われる $(23 、 25)$ 。その後アフィニティーカラムクロマ トグラフィーやそれぞれの抗体に対する 2 次抗体を固定化した カラムがよく使用される。最後に $1 \mathrm{M}$ 塩酸グアニジンで平衡化 されたゲル滤過カラム (Superose 12, Sephacryl S-200) が用いられ る。最後のステップは抗体に非共有結合的に結合している物質 を除くために付け加えられている。DNAニッキング活性をもつ IgG を精製する場合にはDNA を固定化したアフィニティーカラ ムが最終段階で用いられる (30)。これらの精製段階の終了時に は Ig 標品は電気泳動的に均一である $(23 、 25)$ 。しかしヒトアブ ザイムの比活性が低いことを考えると SDS 電気泳動での均一性 は免疫グロブリンそのものに酵素活性があることを証明するに 
abzymes are under consideration. Direct evidences of the presence of amylolytic activity for IgG, IgM, and SIgA fractions of human antibodies are summarized as follows: a) complete adsorption of the considered activity by anti-Abs Sepharose and its elution from the adsorbent with buffer of low $\mathrm{pH}$; b) gelpermeation chromatography of Abs under conditions of "acidic shock" (1 M acetic acid, $\mathrm{pH} 2.6$ ) or in the presence of $6 \mathrm{M}$ guanidine chloride did not lead to a disappearance of the activity, and the peak of activity tracked exactly with Abs (amylolytic activity in the fractions was restored after dialysis); c) Fab fragments obtained by papain digestion of corresponding IgGs and IgMs exhibited the same level of the amylolytic activity. Not less than $80 \%$ of initial amylolytic activity restored after acid shock conditions and $6 \mathrm{M}$ guanidine chloride for both IgG and IgM samples as well as with their Fab fragments $(20,23,25)$.

A further approach was used here for the first time, which provided direct evidence that $\mathrm{IgG} / \mathrm{IgM}$ fractions at autoimmune pathologies and sIgAs from human milk do possess amylolytic activity. After SDS-PAGE of a preparation of native IgG and renaturation, an in-gel assay showed amylolytic activity only in a single protein band corresponding to the complete $150 \mathrm{kDa}$ $\mathrm{H}_{2} \mathrm{~L}_{2}$-form of IgG (Fig. 4). SDS-electrophoresis in non-reducing conditions following by silver staining of the $\operatorname{sg} \mathrm{A}$ fraction revealed two protein bands ( 300 and $380 \mathrm{kDa}$ ), both of which had a positive reaction with anti-IgA Abs by immunoblotting (Fig. 4). The sIgA band of lower electrophoretic mobility corresponded in size to the $380 \mathrm{kDa}\left(\mathrm{L}_{2} \mathrm{H}_{2}\right)_{2} \mathrm{JS}$-form of SIgA containing $1 \mathrm{~S}$-chain, $72 \mathrm{kDa} ; 4$ heavy-chains, $62 \mathrm{kDa} ; 4$ light- chains, $23 \mathrm{kDa}$ and $1 \mathrm{~J}$-chain, $23-26 \mathrm{kDa}$. The $300 \mathrm{kDa}$ form of the $\mathrm{Ab}$ with higher electrophoretic mobility lacks one of the subunits
は不十分である。ヒトアブザイムのタンパク質分解活性や DNA ニッキング活性を示すためにいくつかの厳しい検討がおこなわ れ (12、14)、同様な検討は新規のアブザイムに対して要求され る。 IgG，IgM，および $\operatorname{sgA}$ 分画の澱粉分解活性を示す直接的 な証拠は以下の通りである。a) 抗抗体セファロースにより酵素 活性が完全に吸収され低い $\mathrm{pH}$ で溶出されること; b) 酸性条件 (1 M 酢酸、pH 2.6) または $6 \mathrm{M}$ 塩酸グアニジン存在下において もゲル滤過カラムクロマトグラフィーでの酵素活性のピークが 消失せず、ピーク位置が抗体そのものの溶出位置と一致するこ と(澱粉分解活性は溶出サンプルの透析の後にも保持された)； c) IgG や IgM をパパイン処理して得られる Fab フラグメントにも 同程度の澱粉分解活性があること。実際に IgG および IgM サ ンプルおよびその Fab フラグメントの澱粉分解活性の $80 \%$ 以 上は酸性条件や $6 \mathrm{M}$ 塩酸グアニジン存在下にも保持された $(20$ 、 $23,25)$

さらに自己免疫疾患患者の $\operatorname{IgG} / \operatorname{IgM}$ 分画と母乳の $\operatorname{sIg} A$ が 溊粉分解活性をもつことを示すために初めて用いられた方法を 紹介する。非還元状態でSDS ポリアクリルアミド電気泳動をお こなったのちにゲル内で巻き戻しをおこない澱粉分解活性を測 定すると、活性は $\mathrm{IgG} の \mathrm{H}_{2} \mathrm{~L}_{2}$ - 型の分子量である $150 \mathrm{kDa}$ の位 置に一致して検出された (図4)。sIgA 分画を非還元状態におい てSDS ポリアクリルアミド電気泳動で分離して銀染色を扔こな うと 300 および $380 \mathrm{kDa}$ の 2 本のバンドがみられ、そのいずれ もが抗 IgA 抗体により認識された(図4)。移動度の遅い方のバン
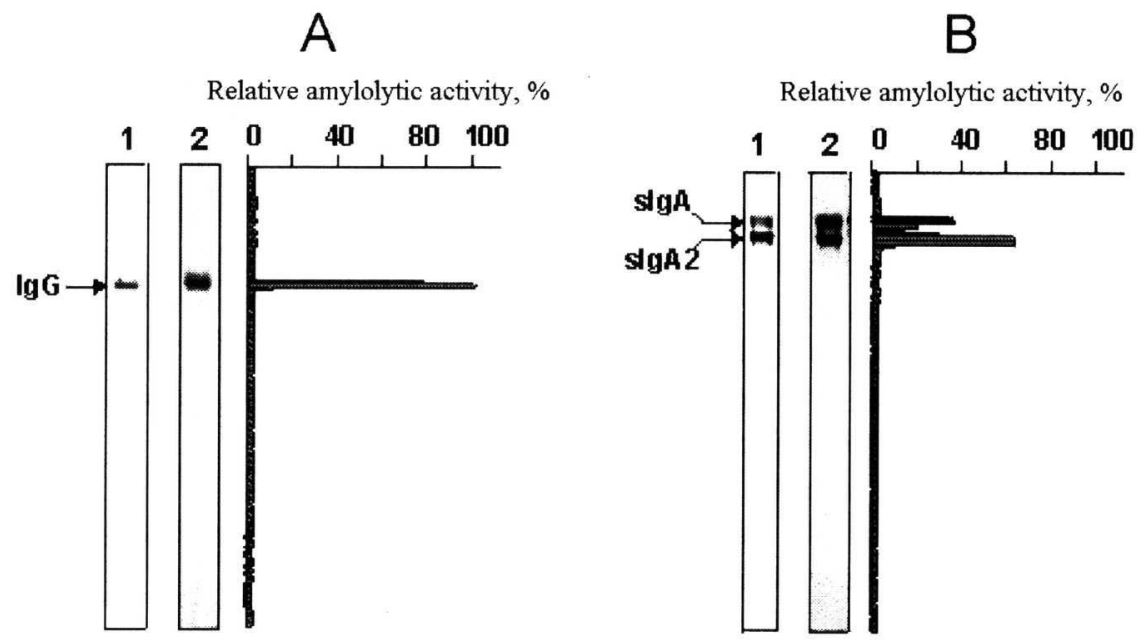

Fig. 4. In situ gel assay of amylase activity of catalytic IgG (A) and sIgA (B) Abs (5-7 $\mu$ g per sample) by SDSPAGE. After electrophoresis the gel was incubated in conditions for renaturation of protein (see Methods) and then the amylase activity was revealed using extracts of $2 \mathrm{~mm}$ slices of the gel (activity shown on the right). Other lanes of the same gel were stained with silver (lanes 2) or were used for revealing the position of the IgG and SIgA by immunoblotting with conjugates of alkaline phosphatase with specific polyclonal anti-IgG (A) and anti-IgA (B) antibodies (lanes 1). 
of the complete $\left(\mathrm{L}_{2} \mathrm{H}_{2}\right)_{2} \mathrm{JS}$-oligomeric form of sIgA and corresponds to a $\operatorname{sIg} \mathrm{A}_{2}$ type of $\mathrm{Ab}$ in which not all light chains are linked covalently to the oligomer by disulfide bonds; such molecules of sIgA can lose light subunits under drastic conditions of $\mathrm{Abz}$ purification $(23,31)$. Elution of $\mathrm{IgG}$ and both $\mathrm{SIgA}$ fractions from the gel after separation by SDS-PAGE allowed isolation of $\mathrm{Ab}$ fractions with amylolytic activity.

As may be seen (Fig. 4), the amylolytic activity strongly corresponds to immunoglobulin bands (23). Similar results were obtained for IgMs from patients suffering from Ms and SLE $(25,26)$. Since SDS dissociates all protein complexes and the electrophoretic mobility of hypothetical contaminating enzymes cannot coincide at the same time with that of IgM and IgG, the detection of amylolytic activity in the gel region corresponding only to the Abs, together with the absence of other bands of the activity or protein, provides direct evidence that the Abs possess amylolytic activity.

Subsequently, we can conclude that we deal with amylolytic activity of human immunoglobulins. Knowledge of kinetic characteristics and mode of action of amylolytic abzymes gives us additional evidence for this.

\section{Hydrolytic Properties of Amylolytic Abzymes}

Hydrolytic parameters of SIgAs and IgGs from human milk as well as IgGs and IgMs from MS and SLE patients were studied in the hydrolysis of starch as well as $\alpha$-D-maltooligosaccharides and PNP-modified $\alpha$-D-maltooligosaccharides of different length. Values for $\mathrm{pH}$ optima of hydrolysis both polymeric, oligomeric and artificial substrates do not vary and lay in the range of 6.57.0 for most of the tested samples. Only a part of IgMs from MS patients has more acid $\mathrm{pH}$ optimum at $4.5-5.5(23-25,32)$. It should be noted that, in all cases, the hydrolytic reactions followed Michaelis-Menten kinetics expressed in linearity of Lineweaver-Burk plots. Values for $K_{\mathrm{M}}$ and $k_{\text {cat }}$ and subsequently the ratio $k_{\mathrm{cat}} / K_{\mathrm{M}}$ were calculated with the assumption that total
ドは $\left(\mathrm{L}_{2} \mathrm{H}_{2}\right)_{2} \mathrm{JS}$ 型の $380 \mathrm{kDa}$ の $\operatorname{sgA}$ (ひとつの $72 \mathrm{kDa} \mathrm{S}$ 鎖、 4 本 の $62 \mathrm{kDa}$ の $\mathrm{H}$ 鎖、4 本の $23 \mathrm{kDa}$ の L 鎖、および 1 本の $23 \sim 26$ $\mathrm{kDa}$ の $\mathrm{J}$ 鎖からなる)に相当した。 $300 \mathrm{kDa}$ のバシドは $\left(\mathrm{L}_{2} \mathrm{H}_{2}\right)_{2} \mathrm{~S}$ 型オリゴマーのサブユニットのひとつを欠くものであり $\operatorname{sigA}_{2}$ に 相当する。これは全ての L 鎖が共有結合している訳ではないの で過激な精製条件で L 鎖を消失している $(23 、 31)$ 。SDS 電気泳 動後のゲルから澱粉分解活性をもった IgG や 2 種類の $\operatorname{sgA}$ を 溶出することができる。

図 4 からわかるように澱粉分解活性は免疫グロブリンのバ ンドと一致している (23)。同様な結果は MS や SLEの患者の IgM についても得られた $(25 、 26)$ 。SDS はタンパク質の複合体を解離 させ、IgM とも IgG とも同じ挙動をする酵素はありえないの で、電気泳動のゲルで抗体の位置にのみ活性が見いだされたと いうことはその抗体自身が澱粉分解活性をもっていることを示 す直接的な証明になる。

そこで私たちはヒト免疫グロブリンが澱粉分解活性をもつ と結論することができる。アブザイムの反応定数や反応のメカ ニズムからさらに詳しい情報が得られる。

\section{D. 澱粉分解活性をもつアブザイムの加水分解様式}

母乳の $\operatorname{sIgAs}$ と IgGs、Ms や SLE 患者の $\operatorname{IgG}$ と IgM による 加水分解定数は澱粉、鎖長の異なる $\alpha-\mathrm{D}-$-マルトオリゴサッカラ イドおよびその PNP 修飾されたものを基質として調べられた。 至適 $\mathrm{pH}$ はほとんどのサンプルにおいてポリマー、オリゴマー、 人工基質のいずれを用いた場合にも $6.5 \sim 7.0$ の範囲であった。 一部の MS 患者の IgM だけが酸性の至適 $\mathrm{pH}(4.5 \sim 5.5)$ を示し た(23-25、2)。すべての場合において反応はミカエリスメンテン

Table I. Kinetic parameters o hydrolysis of PNP maltopentaose catalyzed by several different Abz preparations.

\begin{tabular}{|l|l|l|l|}
\hline Fraction of immunoglobulin* & $K_{\mathrm{M}}, \mathrm{mM}$ & $k_{\text {cat }} \cdot 10^{3}, \mathrm{~s}^{-1}$ & $\begin{array}{l}k_{\mathrm{cat}} / K_{\mathrm{M}},(\mathrm{mM} \cdot \mathrm{s})^{-1} \\
1 \% \mathrm{Abz}\end{array}$ \\
\hline $\mathrm{IgM}_{2}$ (MS patient) & $0.013 \pm 0.001$ & $84 \pm 1$ & $646 \pm 1$ \\
\hline $\mathrm{IgM}_{4}$ (MS patient) & $0.54 \pm 0.01$ & $276 \pm 3$ & $51 \pm 3$ \\
\hline $\mathrm{IgG}_{8}$ (MS patient) & $0.16 \pm 0.01$ & $105 \pm 3$ & $63 \pm 3$ \\
\hline $\mathrm{IgM}_{3}$ (SLE patient) & $0.02 \pm 0.001$ & $290 \pm 3$ & $145 \pm 3$ \\
\hline $\mathrm{IgG}_{3}$ (SLE patient) & $0.22 \pm 0.01$ & $205 \pm 3$ & $93 \pm 3$ \\
\hline $\mathrm{IgM}_{5}$ (SLE patient) & $0.44 \pm 0.01$ & $805 \pm 3$ & $183 \pm 3$ \\
\hline $\mathrm{IgG}_{2}$ (human milk) & $0.16 \pm 0.01$ & $54 \pm 1$ & $33 \pm 1$ \\
\hline $\mathrm{IgG}_{6}$ (human milk) & $0.14 \pm 0.01$ & $10 \pm 1$ & $8 \pm 0.5$ \\
\hline $\mathrm{sIgA}_{16}$ (human milk) & $0.12 \pm 0.01$ & $25 \pm 1$ & $20 \pm 1$ \\
\hline sIgA $_{53}$ (human mik) & $0.14 \pm 0.01$ & $28 \pm 1$ & $21 \pm 1$ \\
\hline
\end{tabular}

*Subscripts correspond to patient numbers. 
Ig fraction contains not more than $1 \%$ of amylolytic abzymes. Kinetic data for the hydrolysis of PNP maltohexaose catalyzed by abzymes from human milk and patients with autoimmune diseases are given in Table I. In contrast to $\mathrm{SIgAs}$ and IgGs from human milk, for which $K_{\mathrm{M}}$ values were in the range $0.1-0.2 \mathrm{mM}$ (23), only some IgM samples from MS and SLE patients showed $K_{\mathrm{M}}$ values of two orders of magnitude lower $(25,26)$. Such low (in $\mu$ mole range) values of $K_{\mathrm{M}}$ are characteristic for human Abzs reported for DNA and protein-hydrolyzing polyclonal IgGs from human sera and milk $(12,14,33)$. Analysis of obtained data on catalytic efficiencies $\left(k_{\text {cat }} / K_{\mathrm{M}}\right)$, which were calculated based on the assumption that $1 \%$ of total Igs are amylolytic, show that the values are in the range from $10^{2}$ to $10^{4}(\mathrm{~s} \cdot \mathrm{mM})^{-1}$ that, in principal, coincide with catalytic efficiency of traditional glycoside hydrolases. The most important characteristic of the hydrolytic reactions catalysed by antibodies is a ratio $k_{\text {car }} / k_{\text {uncat }}$, which for amylolytic Abzs ranges in $10^{4}-10^{5}$ and is similar for most other abzymes (1-4).

The dependence of the catalytic efficiencies $\left(k_{\text {cat }} / K_{\mathrm{M}}\right)$ on the substrate length can be used to derive useful information about the active site of the depolymerases, namely the number of substrate binding sites available for oligomeric substrates. The dependence of the kinetic parameters $K_{\mathrm{M}}$ and $k_{\text {cat }}$ on the substrate length was investigated with $\operatorname{IgM}$ fractions isolated from MS patients. IgMs tested did not exhibit $\alpha$-glucosidase activity and were not able to cleave the short substrates PNPG $_{2}$ and $\mathrm{PNPG}_{3}$, although they were active towards $\mathrm{PNPG}_{4}$ through $\mathrm{PNPG}_{8}$, thus demonstrating an exo-pattern of action. Values for $k_{\text {cat }}$ decrease as the degree of substrate polymerization increases, while the effect of the substrate length on the $K_{\mathrm{M}}$ is more com-
型を示し、両逆数プロットは直線上にのった。 $K_{\mathrm{M}}$ と $k_{\text {cal }}$ 值とそ の比 $k_{\mathrm{cat}} / K_{\mathrm{M}}$ はアブザイムは全免疫グロブリンのうちの $1 \%$ で あるという仮定で計算された。母乳と自己免疫疾患患者のアブ ザイムによるPNPマルトヘキソースの分解の酵素学的定数を表 Iに示す。母乳の $\operatorname{sIgAs}$ と IgGs の場合の $K_{\mathrm{M}}$ 值は $0.1 \sim 0.2 \mathrm{mM}$ で あるのに対して (23)、MS や SLE 患者からの IgMのあるものは きわめて低い $K_{\mathrm{M}}$ 值を示した $(25 、 26)$ 。そのように低い $K_{\mathrm{M}}$ 值 $\mathrm{Y}$ はヒトの血清や母乳の IgG の DNA やタンパク質分解活性をも つアブザイムに特有なものである $(12 、 14 、 33)$ 。アブザイム含量 を $1 \%$ と仮定して計算した場合の触媒効率 $\left(k_{\mathrm{cas}} / K_{\mathrm{M}}\right)$ の值は $10^{2}$ to $10^{4}(\mathrm{~s} \cdot \mathrm{mM})^{-1}$ であってグリコサイドハイドロラーゼのものと 同程度である。抗体による加水分解反応でもっとも重要な值は $\left(k_{\mathrm{cal}} / K_{\mathrm{M}}\right)$ である。澱粉分解活性をもつアブザイムでは $10^{4} \sim 10^{5}$ で あり他のアブザイムの場合と似た值である (1-4)。

$k_{\mathrm{ca}} / K_{\mathrm{M}}$ 值の基質の長さに対する依存性から触媒部位の数、す なわち基質の結合の部位の数に関する知見が得られる。MS 患者 の $\operatorname{IgM}$ について $K_{\mathrm{M}}$ と $k_{\text {cal }}$ の基質の長さに対する依存性が検討 された。このIgMは $\alpha$-グルコシダーゼ活性をもたず短い $\mathrm{PNPG}_{2}$ と $\mathrm{PNPG}_{3}$ を分解することはできないが $\mathrm{PNPG}_{4}$ から $\mathrm{PNPG}_{8}$ まで は分解できた。これはエキソ型の作用を示している。鎖長が長 くなるほど $k_{\mathrm{cat}}$ 值は低下した。 $K_{\mathrm{M}}$ 值に対する効果はもっと複雑 であった。いくつかのサンプルに抒ける加水分解反応の基質重

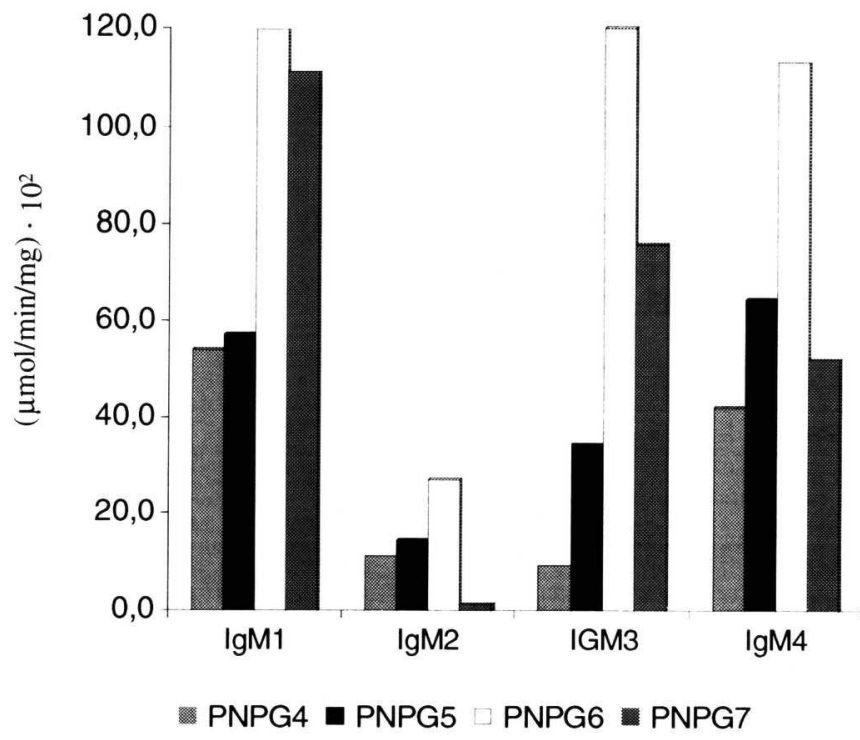

Fig. 5. Comparison of the relative velocity values for the abzyme-mediated hydrolysis of PNP maltooligosaccharides with d.p. 4-7 by several selected immunoglobulins. Numerals correspond to patient numbers. 
plex. Dependences of hydrolytic velocities on d.p. of the substrates for several preparations are given in Fig. 5.

One more characteristic of subsite structure of amylolytic Abzs can be the inhibition constants $\left(K_{\mathrm{I}}\right)$, which were estimated for $\alpha$-D-maltooligosaccharides of different lengths using EPS as a substrate. It should be noted that in all cases the inhibition of EPS-maltoheptaoside hydrolysis by maltooligosaccharides was competitive with respect to the substrate. For SIgA fractions from human milk, glucose, maltose, and maltotriose inhibited hydrolysis of EPS-hexaoside at a high concentration $\left(K_{\mathrm{I}}\right.$ $>20 \mathrm{mM}$ ), while further lengthening of the oligomer led to a graduate increase of the ligand's affinity. Interestingly, the $K_{\mathrm{I}}$ value for maltohexaose is of the same order of magnitude as the $K_{\mathrm{M}}$ values for EPS-hexaoside for several preparations of IgG and $\operatorname{sIgA}(23,24)$.

Transglycosylation, an inversion of the hydrolytic reaction, is a well-known feature of retaining glycoside hydrolases. Transglycosylating ability has been reported for $\alpha$-amylases including human salivary $\alpha$-amylase (34), a retaining glycosidase devoted to 13 glycoside hydrolase family according to Henrissat classification (http://afmb.cnrs-mrs.fr/CAZY/) (35). The reactions of substrate transglycosylation using various PNP maltooligosaccharides were studied for a set of different types of Igs exhibiting amylolytic activity. The transglycosylating activity of Abzs was investigated in the reaction of $\mathrm{PNPG}_{3}$ using substrate concentrations up to $150 \mathrm{mM}$. As demonstrated by HPLC and TLC analysis, none of the amylolytic Ig fractions produced PNP maltooligosaccharides with a d.p. greater than 3, as would be expected if transglycosylation was occurring. When PNPG was used as a substrate for abzyme transglycosylation, neither $\mathrm{PNPG}_{2}$ nor $\mathrm{PNPG}_{3}$ were detected in the reaction mixture. Furthermore, the transglycosylation activity of selective IgMs was analysed using $\mathrm{PNPG}_{4}, \mathrm{PNPG}_{5}$, and $\mathrm{PNPG}_{6}$ at $10 \mathrm{mM}$ concentration. In all cases, no transglycosylation products were detected. The same behaviour demonstrated SIgAs and IgGs isolated from human milk.

\section{Catalytic Microheterogeneity of Abz Action}

Differences in Abz's action modes show much more clearly the catalytic heterogeneity of Igs than comparison of kinetic parameters of different preparations of human Abzs. The most vivid difference is that a part of Ig samples exhibits exo-amylase activity, while another demonstrates also $\alpha$-glucosidase action expressed in Abz ability to hydrolyze short maltooligosaccharides. Therefore, all tested Ig preparations can be divided into two main groups according to their action patterns. Such differences in action modes have been detected for all studied types of immunoglobulins with amylolytic activity (22-26). Data on the presence of $\alpha$-D-glucosidase activity (i.e. the ability to cleave off PNP $\alpha$ D-glucopyranoside) in different samples of IgM and IgG from MS patients are introduced in Fig. 6.
合度への依存性を図 5 に示す。

澱粉分解活性をもつアブザイムの触媒部位の構造に関する もうひとつの情報として EPS ヘキソサイドを基質とした場合の 鎖長の異なる $\alpha-\mathrm{D}-$ マルトオリゴサッカライドの阻害定数 $\left(K_{1}\right)$ が あげられる。この阻害の様式はいつでも拮抗的であった。ヒト 母乳の $\operatorname{sgA}$ 分画に打いてグルコース、マルトース、マルトトリ オースの阻害定数は $20 \mathrm{mM}$ 以上であったがオリゴマーがさらに 長くなると親和性が徐々に増加した。いくつかの IgG, $\operatorname{sIgA} に$ おいマルトヘキサオースの阻害定数は EPS-ヘキソサイドの $K_{\mathrm{M}}$ 值と同程度である $(23 、 24)$ 。

加水分解反応の逆反応であるトランスグリコシレーション はグリコシド結合分解酵素のよく知られた性質である。トラン スグリコシレーション活性はヒト唾液腺 $\alpha$-アミラーゼ (34)、 Henrissat の分類 (http://afmb.cnrs-mrs.fr/CAZY/) による 13 種類の グリコシド分解酵素ファミリー (35) について報告されている。 さまざまな PNPマルトオリゴサッカライドを用いて澱粉分解活 性をもつ免疫グロブリンのトランスグリコシレーション活性が 調べられた。 $150 \mathrm{mM}$ までの基質濃度に対して $\mathrm{PNPG}_{3}$ へのトラ ンスグリコシレーションの活性が測定された。HPLC と TLC 分 析の結果では澱粉分解活性をもつ免疫グロブリンによる鎖長が 3 より長い PNP マルトオリゴサッカライド(トランスグリコシ レーションが起こった場合に想定される生成物) の生成は認めら れなかった。PNPG をアブザイムトランスグリコシレーション の基質として用いた場合 $\mathrm{PNPG}_{2}$ も $\mathrm{PNPG}_{3}$ も検出されなかった。 さらに IgM に対して $10 \mathrm{mM}$ までの $\mathrm{PNPG}_{4}, \mathrm{PNPG}_{5}$, and $\mathrm{PNPG}_{6}$ を用いた場合にもトランスグリコシレーションの生成物は検出

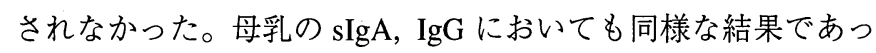
た。

\section{D. アブザイムの触媒作用の多様性}

異なるヒトアブザイム標品において速度パラメーターより も作用メカニズムに扔いてょり明確な不均一性が見られる。 もっとも顕著な差はある種の免疫グロブリンはエキソ型アミ ラーゼ活性を示すのに対して、あるものは短いマルトオリゴ サッカライドも分解できるグルコシダーゼ活性ももつ点であ る。澱粉分解活性をもつ免疫グロブリンはいずれも作用にもと

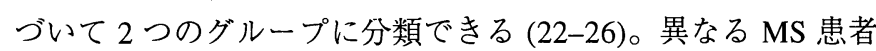
の IgM, IgG の $\alpha$-D-グルコシダーゼの検出 (PNP $\alpha$-D-グルコピラ ノシドの分解)の結果を図 6 に示す。 


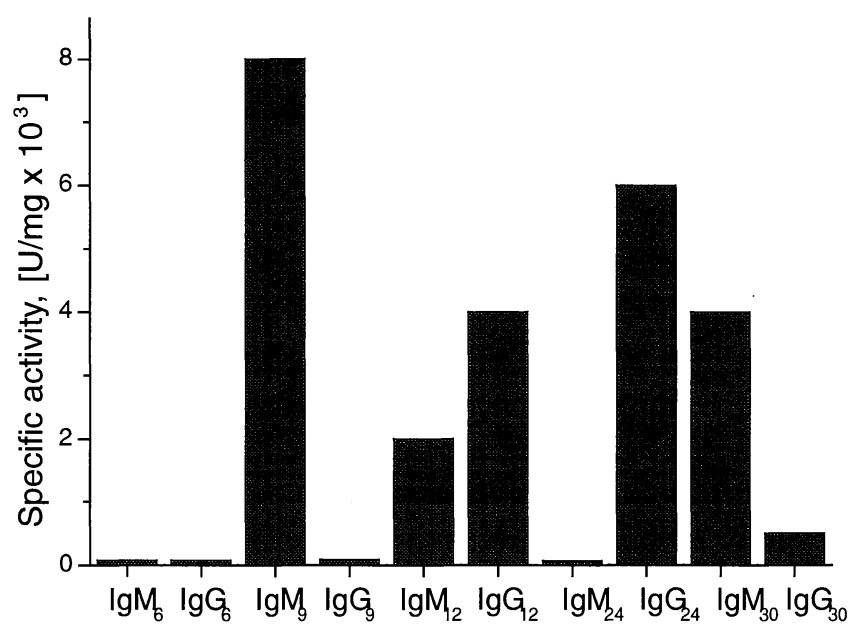

Fig. 6. $\alpha$-Glucosidase activity in PNP-Glc hydrolysis effected by IgMs and IgGs preparations from sera of SLE patients.

Analysis of a ratio of hydrolytic products within both groups (exo-amylolytic Abzs and exo-amylase/ $\alpha$-D-glucosidase acting antibodies) also reveals catalytic microheterogeneity. Thus, several preparations of human milk sIgA and IgG devoted to the exo-amylase action group showed differences in relative contents of the hydrolytic products after the same conversion of maltooligosaccharides with d.p. 3-6 for each of the abzyme samples (23).

Reliable evidence of microheterogeneity of modes of action can be derived from the analysis of hydrolytic activities of Abzs using artificial substrates, PNP- or MeUmb $\alpha$-Dmaltooligosaccharides with various d.p. Product comparison of the MeUmb maltotetraose hydrolysis by a set of SLE IgMs resulted also in distinguishing of Abzs into two groups: the first was able to liberate free MeUmb during the hydrolysis in contrast to another one. Therefore, within exo-amylase-like acting Abzs we see two sub-groups, differentiated by their modes of action. The first is unable to bind MeUmb in the site +1 of the active center while the second performs this connection yielding free MeUmb during the hydrolysis (Fig. 7).

From our point of view, the most reliable evidence for the inherent amylolytic activity of human antibodies is a variability of action patterns displayed by abzyme fractions. One could only explain differences in samples isolated by a standard procedure by the presence of contaminating enzymes with different types of amylolytic activity in milk and sera of different donors, a hypothesis which we believe is very unlikely.

Summarizing all the results obtained on enzymatic properties of amylolytic human antibodies, we can show vivid differences between traditional human $\alpha$-amylases and amylolytic antibodies. First of all, it is commonly accepted that $\alpha$-amylases are retaining glycoside hydrolases, which possess transglycosylating abilities (34). Contrariwise, amylolytic abzymes do not reveal any transglycosylating properties. Sec-

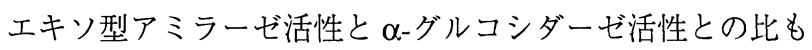
触媒活性の不均一性を示している。エキソ型アミラーゼ活性を もついくつかの母乳の $\operatorname{sIgA}, \operatorname{IgG}$ 標品において重合度 3〜6の マルトオリゴサッカライドの分解産物の相対的な割合には差異 がみられる (23)。

作用機序に不均一性があることを示す信頼できる根拠は重 合度の異なる PNP-およびメチルウンベリル $\alpha$-D-マルトオリゴ サッカライドを人工基質として用いたアブザイムの加水分解作 用の解析によって得られる。SLE 患者の IgMによるメチルウン ベリルマルトオリゴサッカライドの加水分解物の比較によって も2つのグループが区別できる：メチルウンベリルを遊離でき るものとできないものに。エキソ型アミラーゼ様アブザイムの 中でも作用の異なる 2 つのグループがある。1つはメチルウン ベリルを活性部位の +1 位に結合できないもので、もう 1 つは +1位に結合することによりメチルウンベリルを加水分解の途中 で遊離するものである (図7)。

私たちの考えではアブザイム分画の作用の多様性こそヒト 抗体に固有の澱粉分解活性があることを示すもっとも強い証拠 となる。サンプル間の差異を、混入している酵素の差異(異なる ドナーからの血清と母乳の酵素)だけで説明する仮説はきわめて 考えにくいものである。

澱粉分解活性をもつヒト抗体の酵素学的性質をまとめると $\alpha$-アミラーゼと澱粉分解醭素活性をもつ抗体との明確な差を示 すことができる。第一に $\alpha-$ アミラーゼにはグルコシド分解活性 がありトランスグリコシレーション活性をもつことがよく知ら れている (34)。これに対して澱粉分解活性をもつアブザイムに はトランスグリコシレーション活性はない。第二にアブザイム 


\section{Schematic representation of amylolytic abzyme active center and its binding sites}

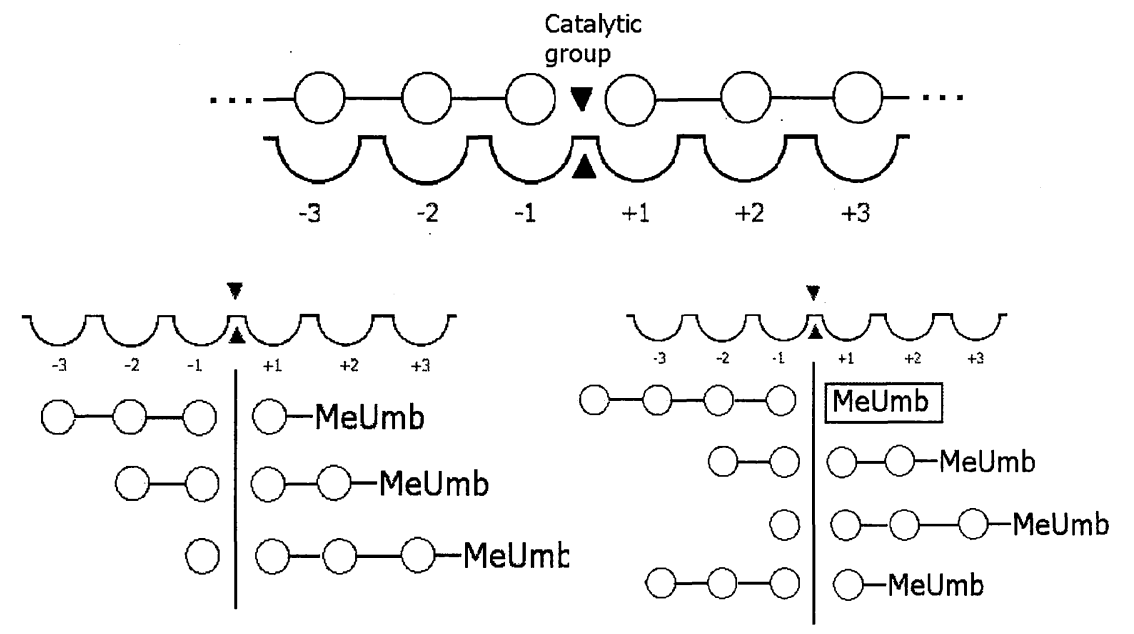

Fig. 7. Different action-patterns for SLE amylolytic abzymes.

ond, it is an independence of the initial rate of the hydrolysis by abzymes on the length of a substrate while human salivary $\alpha$ amylase show linear increase of the initial hydrolytic velocity along with substrate degree of polymerization $(21,22)$. Third, human salivary $\alpha$-amylase requires chloride ions for the activity (36) in contrast to amylolytic antibodies. Undoubtedly proved inherent amylolytic activity of immunoglobulins is essential due to one more reason. The association of $\alpha$-amylase with immunoglobulin fractions from human blood has been described in a macroamylasemia disease in which human sera $\alpha$-amylases formed high molecular weight complexes associated with blood immunoglobulins (37).

\section{E. Why do Abzymes Appear? Hypotheses for Mechanisms of Formation}

Although the first catalytic antibodies were discovered in the blood of humans about ten years ago, there is no unequivocal explanation of the mechanism of arising abzymes with enzymatic activities both in the sera of patients with autoimmune pathologies and in milk of clinically healthy women. Many investigators who are working in a field of abzymes agree that both mechanisms widely used for the generation of monoclonal antibodies in vitro (immunization against 'transition-state analog' of the reaction and approach of anti-idiotypic antibodies) could be realized in the formation of catalytic human antibodies. For example, catalytic polyclonal antibodies capable of hydrolyzing carbomate ester were reported to be produced after immunization against transition-state analog conjugated with BSA (27). It was Jerne et al. who introduced anti-idiotypic hypothesis of antibody formation (Fig. 8) (38). In anti-idiotypic sequence, $\mathrm{Ab} 1$ is antibody against the enzyme active center (an-
による加水分解の初速度は基質の重合度に依存しないがヒト唾 液腺 $\alpha$-アミラーゼの場合は重合度の増加とともに反応の初速度 も直線的に増加する $(21 、 22)$ 。第三にヒト唾液腺 $\alpha$-アミラーゼ は活性に塩素イオンを必要とするが (36)、酵素の場合は必要と しない。免疫グロブリンには $\alpha$-アミラーゼの結合では説明でき ない固有の澱粉分解活性があることを示すもうひとつの理由が ある。それは巨大アミラーゼ血症において血清中の $\alpha$-アミラー ゼが免疫グロブリンと結合した場合には高分子量の複合体を形 成することである (37)。

E. なぜアブザイムは出現するのか？ 生成メカニズムに関する 仮説

活性をもつ抗体がヒトの血液中に発見されてから約 10 年に なるが自己免疫疾患患者の血清と健康な母親の母乳にアブザム が出現する理由は完全にはわかっていない。アブザイムの研究 者の多くはアブザイムの生成には in vitro におけるモノクローナ ル抗体の生成 (遷移状態アナログに対する免疫や抗イデイオタイ プ抗体の作成)を適用できると考えている。たとえばBSA に結 合させた遷移状態アナログを免疫することによりカルバメート エステルを加水分解できる抗体を作成できることが報告されて いる (27)。 Jerne らは抗イデイオタイプ抗体の仮説を導入した (図8) (38)。

$\mathrm{Ab} 1$ は酵素の触媒部位を抗原とする抗体である。Ab2 は Ab1 


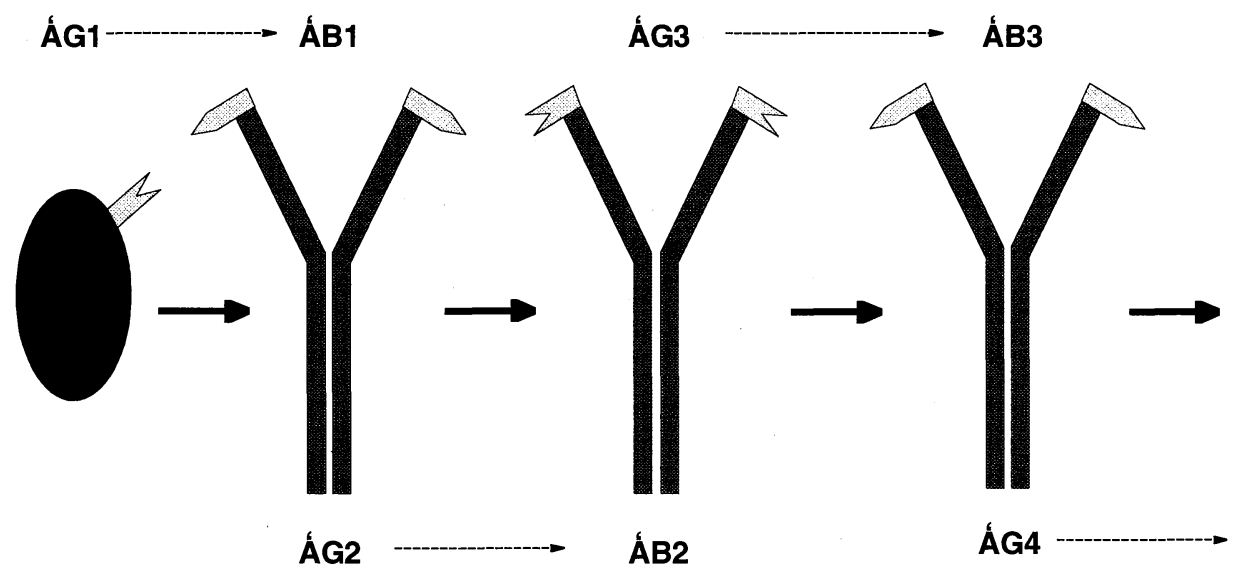

Fig. 8. Schematic representation of formation of anti-idiotypic antibodies.

tigen); $\mathrm{Ab} 2$ is a secondary antibody against fragments of $\mathrm{Ab} 1$ and can have a similar primary and tertiary structure with the enzyme active center and therefore, display enzymatic activity. This sequence can be prolonged yielding catalytically inactive Ab3 and active Ab4.

In a number of works was shown that autoimmune diseases, in particular MS, associate with a large amount of DNA fragments and DNA-binding antibodies found in the sera of patients (39). It also strongly correlates with the existence of DNA-nicking catalytic antibodies. Therefore, we can suppose that some conformers of DNA fragments in the sera of donors with autoimmune pathologies quite precisely imitate the transition state of DNA hydrolysis leading subsequently to the generation of catalytic antibodies in frames of the first suggested approach. However, the second, 'anti-idiotypic' approach also can work here assuming that primary, secondary and further antibodies are being elicited against DNA-binding antibodies, which arise initially in the sera of patients with autoimmune diseases.

We cannot also exclude the possibility that some potential antigens can change their conformation due to interaction with certain proteins or enzymes and, as a consequence, the structure of the antigens in such complexes can mimic the structure of the transition state of the reaction involving this antigen conversion. It should be noted that a link between autoimmune disease and autoantibody-mediated catalysis is also suggested by observations that a mouse strain with a genetic predisposition to autoimmune disease mounts unusual catalytic antibody responses to transition state analogs (40).

What possible mechanisms of abzyme formation are there in human milk? Human milk contains various types of Abzs (IgG, IgM, IgA and SIgA), of which sIgA is the major component (> 85-90\%). As reported earlier, IgG and sIgA from healthy mother's milk possesses different catalytic activities. Moreover,
に対する 2 次抗体であり、醅素の触媒部位に似た 1 次構造およ び3 次構造をとるために酵素活性をもつ。このような反応が続 くと活性をもたない $\mathrm{Ab} 3$ および活性をもつ Ab4 が出現する。

自己免疫疾患、特に多発性硬化症では、血清中に大量の DNA 断片と DNA に結合する抗体がみられる (39)。これはDNA ニッキング活性をもつ抗体の存在と密接に関係する。このこと から自己免疫疾患患者の血清中の DNA 断片はきわめて正確に 加水分解中の DNA の遷移状態に近い構造をとるために酵素活 性をもつ抗体を出現させるのではないかという推論が生まれ る。また第二の仮説である抗イデイオタイプ抗体説も考えられ る。すなわち自己免疫疾患患者の血清中に DNA に結合する自 己抗体が存在していて、それに対する抗体が次々に産生される というものである。

潜在的な抗原が、あるタンパク質または酵素との相互作用 により構造変化を起こして遷移状態と近い構造をとる可能性も 否定できない。自己免疫疾患になりやすい遺伝的傾向のあるマ ウスの系統では遷移状態アナログに対する抗体の反応性が異常 であるという報告は自己免疫疾患と自己抗体による触媒反応と の間の関連性を示唆する (40)。

ヒト母乳におけるアブザイム生成のしくみはどのようなも のだろうか。ヒト母乳にはさまざまなアブザイム (IgG, IgM, IgA and $\operatorname{sIg} \mathrm{A})$ が含まれ、なかでも $\operatorname{sg} A$ が主成分である (> 85 90 \%)。初期に報告されたようにヒト母乳の IgG と $\operatorname{sgA}$ では触媒 活性が異なる。さらに活性をもつ IgG が授乳期の母親の血清に も検出される。粘膜免疫では体液免疫とは異なる抗体、特に分 
Trends in Glycoscience and Glycotechnology Vol.16 No.87 (January 2004) pp.17-31

catalytic IgGs were detected in blood sera of mothers during the lactation period. Different antibodies and especially secretory immunoglobulins A are the main effectors of the mucosal immune system and their protective aspects are well documented (41). Milk contains a wide array of Abs to bacterial, viral, and protozoal antigens (42) with antimicrobial activity, which reach mucosal surfaces of intestinal and respiratory tracts and as a result protect infants from infection and disease. However, the mechanism by which sIgAs exert their antimicrobial activity is still a matter of debate. As yet, many sIgA protective functions have been demonstrated such as neutralisation and agglutination of pathogens, activation of alternate complement pathways, inhibition of foreign antigen entry into the mucosa and attachment (43). Pregnancy could "activate" or "trigger" autoimmunelike manifestations in clinically healthy women, and a sharp exacerbation of autoimmune reactions can occur in some cases soon after childbirth. Recently, it was demonstrated that a process of autoimmunization leading to production of natural Abzs occurs both in serum of healthy pregnant women and in the milk of lactating mothers. It is more than likely that the formation of such an amount of polyclonal catalytic antibodies in human milk may be explained by anti-idiotypic theory.

What are the possible pathways of formation of amylolytic abzymes in humans with autoimmune diseases and in human milk? One can suppose that similar mechanisms occur in both cases due to quite strong similarity in enzymatic properties between IgM/IgG preparations from autoimmune patients and autoantibodies from human milk. A short review of successful attempts to produce monoclonal antibodies with glycoside hydrolase activities in vitro can clarify this question. A wellknown analogue of transition state of glycoside hydrolase reactions, 1-deoxynajirimycin (an inhibitor of $\alpha$-glucosidases and glucoamylases) (44), was used several times after its modification with PNP for generation of monoclonal antibodies (45). It has also been shown that even glycoside hydrolase inhibitors not conjugated to a carrier protein can act as haptens for the production of antibodies with targeted glycosidase activity. As a result, abzymes displayed $k_{\text {cat }} / K_{\mathrm{M}}$ ratios in the range 100-1000 $(\mathrm{s} \cdot \mathrm{mM})^{-1}$ and possessed various glycoside hydrolase specificities. Thus, series of monoclonal antibodies manifesting $\beta$-D-glucosidase, $\alpha / \beta$-D-galactosidase, $\beta$-D- $N$-acetylglucosaminidase, $\beta$ $D$-fucosidase activities along with $\alpha$-glucosidase function were reported $(45,46)$. Such absence of strict specificity can be explained if we take into consideration that transition state analogues imitating pyranose rings do not give absolute specificity towards glucose at immune response. In our case, the absence of other glycoside hydrolase activities than $\alpha$-amylolytic and $\alpha$-glucosidase activities in IgM/IgG fractions isolated from the sera of autoimmune patients suggests that at a quite high degree of probability anti-idiotypic mechanism of their generation occurs at autoimmune pathologies. Indeed, this approach can lead
泌型 IgA (sIgA)、が中心的な役割を果たして生体防御にかかわ ることはよく知られている (41)。母乳には細菌、ウイルス、か ら寄生虫といったさまざまな抗原に対する抗菌作用をもつ抗体 が含まれ (42)、乳児の小腸や気道の粘膜面からの感染や病気を くい止めている。SIgA の抗菌作用についてはまだ議論がある が、病原体の中和や凝集、補体系活性化、外来抗原の進入や接 着阻止といったさまざまな防御的作用が示されている (43)。妊 娠は健康な女性に自己免疫疾患に似た応答を活性化させる、ま たは引き起こすものであり、出産直後から自己免疫応答が昂進 する。最近、アブザイム生成に至る自己免疫応答は健康な妊娠 している女性の血清においても授乳中の母親の母乳においても 起こっていることが示された。ヒト母乳における触媒活性をも つポリクローナル抗体の生成は抗イディオタイプ抗体によるも のであるかもしれない。

自己免疫疾患患者と母乳に澱粉分解活性をもつアブザイム が出現する経路はどのようなものだろうか。自己免疫疾患患者 の $\mathrm{IgM} / \mathrm{IgG}$ 分画とヒト母乳の自己抗原の酵素学的性質はきわめ て似ているので両者は共通したしくみで生成されると考えられ る。グリコシド結合分解活性をもつモノクローナル抗体を in vitroで作成することに成功した試みからこの問題を考えてみよ う。よく知られているグリコシド結合分解反応の遷移状態アナ

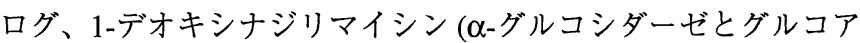
ミラーゼの阻害剤) (44)、はPNPで修飾された後にモノクロー ナル抗体を作成するために用いられた (45)。キャリアタンパク 質に結合させていないグルコシダーゼ阻害剤であってもグルコ シダーゼと同じ活性をもつ抗体が生じた。得られたアブザイム の $k_{\mathrm{cal}} / K_{\mathrm{M}}$ 值は $100 \sim 1000(\mathrm{~s} \cdot \mathrm{mM})^{-1}$ であり $\alpha-$ グリコシド結合を もつさまざまな基質に対して反応した。すなわち $\beta$-グルコシ

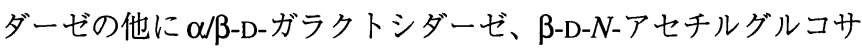
ミニダーゼ、 $\beta$-D-フコシダーゼ活性をもつ一連のモノクローナ ル抗体が報告された $(45 、 46)$ 。このように厳密な基質特異性がな いことはピラノース環を真似た遷移状態アナログが免疫応答に おいてはグルコースとして特異的に認識されなかったためと考 えると説明できる。一方自己免疫疾患患者の血清の IgM/IgG 分 画の場合は澱粉分解活性とグルコシダーゼ活性以外のグリコシ ド結合分解活性をもたないので、遷移状態アナログに対する抗 体産生よりは抗イデイオタイプ抗体産生によるアブザイム出現 の可能性が高い。抗イディオタイプ抗体の場合には高い立体特 
to high stereospecificity and steroselectivity of abzymes produced in human sera and milk.

The discovery of the phenomenon of amylolytic autoantibodies at autoimmune abnormalities reveals direct therapeutic effect. As individual MS patients demonstrate a broad range of clinical symptoms, types of disease progress, and autoimmune status, etc, the definitive diagnosis of MS is still a very difficult challenge. Since in our experiments nearly $100 \%$ of the MS patients were characterized by high amylolytic activity of IgMs, analysis of this activity by highly sensitive methods using 4methylumbelliferyl maltooligosaccharides can probably be used as an additional criterion for this pathology.

\section{Acknowledgements}

This work was supported in part by grants from the Presidium of Academy of Sciences (Program "Physico-Chemical Biology"), RFBR (No. 03-04-48756) and a grant from the 6-th Competition-Examination for Young Scientists of RAS on Fundamental and Applied Researches.
異性と立体選択性をもつことが可能である。

自己免疫疾患に扔ける澱粉分解活性をもつ自己抗体の発見 は臨床応用に直結する。多発性硬化症は臨床的にさまざまな兆 候、症状の経過、自己免疫の状態を示し確定診断は現在でも非 常にむずかしい。私たちの研究では多発性硬化症患者はほほ 100 \%の場合において IgMに高い澱粉分解活性がみとめられた。4メチルウンベリフェリル マルトースオリゴサッカライドを用 いた高感度測定法は多発性硬化症の新しい診断法として利用可 能であろう。

\section{東京医科歯科大学歯学部}

横山 三紀訳

\section{References}

1. Tramontano, A., Janda, K.D., and Lerner, R.A. (1986) Science 234, 1566-1569

2. Lerner, R.A., and Tramontano, A. (1981) Sci. Am. 258, 58-60

3. Lerner, R.A., Benkovic, S.J., and Shultz, P.J. (1991) Science 252, 659-667

4. Benkovic, S.J. (1992) Annu. Rev. Biochem. 61, 29-54

5. Li, T., Janda, K.D., Ashley, J.A., and Lerner, R.A. (1994) Science 264, 1289-1293

6. Janda, K.D., Weinhouse, M.I., Schloeder, D.M., and Lerner, R.A. (1990) J. Am. Chem. Soc. 112, 1274-1275

7. Janda, K.D., Shevin, C.G., and Lerner, R.A. (1993) Science 259, 490-492

8. Hilvert, D. (1992) Pyre Appl. Chem. 64, 1103-1113

9. Suzuki, H. (1994) J. Biochem. 115, 623-628

10. Izadyar, L., Friboulet, A., Remy, M.H., Roseto, A., and Thomas, D. (1993) Proc. Natl. Acad. Sci. USA 90, 8876

11. Paul, S., Volle, D.J., Beach, C.M., Jonson, D.R., Powell, M.J., and Massey, R.J. (1989) Science 244, $1158-1162$

12. Kalaga, R., James, L.L., O’Dell, J.R., and Paul, S. (1995) J. Immunol. 155, 2695-2702

13. Shuster, A.M., Gololobov, G.V., Kvashuk, O.A., Bogomolova, A.E., Smirnov, I.V., and Gabibov, A.G. (1992) Science 256, 665-667

14. Gololobov, G.V., Chernova, E.A., Schourov, D.V., Smirnov, I.V., Kudelina, I.A., and Gabibov, A.G. (1995) Proc. Natl. Acad. Sci. USA 92, 254-257

15. Vlassov, A., Florentz, C., Helm, M., Naumov, V., Buneva, V., Nevinsky, G., and Giege, R. (1998) Nucleic Acids Res. 26, 5243-5250

16. Andrievskaia, O.A., Buneva, V.N., Naumov, V.A., and Nevinsky, G.A. (2000) Med. Sci. Monit. 6, 460-470

17. Nevinsky, G.A., and Buneva, V.N. (2002) J. Immunol. Methods 269, 235-245

18. Kanyshkova, T.G., Semenov, D.V., Chlimankov, D.Y., Buneva, V.N., and Nevinsky, G.A. (19970 FEBS Lett. 416, 23-27

19. Buneva, V.N., Kanyshkova, T.G., Vlassov, A.V., Semenov, D.V., Khlimankov, D.Y., Breusova, L.R., and Nevinsky, G.A. (1998) Appl. Biochem. Biotechnol. 75, 63-76

20. Savel'ev, A.N., Eneyskaya, E.V., Shabalin, K.A., Filatov, M.V., and Neustroev, K.N. (1999) Prot. Pept. Lett. 6, 179-184

21. Brayer, G.D., Sidhu, G., Maurus, R., Rydberg, E.H., Braun, C., Wang, Y., Nguyen, N.T., Overall, C.M., and Withers, S.G. (2000) Biochemistry 39, 4778-4791

22. Suganuma, T., Ohnishi, M., Hiromi, K., Nagahama, T. (1996) Carbohydr. Res. 282, 171-180

23. Savel'ev, A.N., Kanyshkova, T.G., Kulminskaya, A.A., Buneva, V.N., Eneyskaya, E.V., Filatov, M.V., Nevinsky, G.A., and Neustroev, K.N. (2001) Clin. Chim. Acta 314, 141-152

24. Ivanen, D.R., Kulminskaya, A.A., Ershova, N.A., Eneyskaya, E.V., Shabalin, K.A., Savel'ev, A.N., Kanyshkova, T.G., Buneva, V.N., Nevinsky, G.A., and Neustroev, K.N. (2002) Biologia (Bratislava) 57, 253-260

25. Saveliev, A.N., Ivanen, D.R., Kulminskaya, A.A., Ershova, N.A., Kanyshkova, T.G., Buneva, V.N., Mogelnitskii, A.S., Doronin, B.M., Favorova, O.O., Nevinsky, G.A., and Neustroev, K.N. (2003) Immunol. Lett. 86, 291-297

26. Neustroev, K.N., Ivanen, D.R., Kulminskaya, A.A., Brumer, 3rd, H., Saveliev, A.N., Nevinsky, G.A. (2003) Human Antibodies 12, 31-34

27. Wang, J., Han, Y., Wilinson, M.F. (2001) Biochem. J. 360, 151-157

28. Paul, S., Li, L., Kalaga, R. O’Dell, J., Dannenbring, R.E. Jr., Swindells, S., Hinrichs, S., Caturegli, P., and Rose, N.R. (1997) J. Immunol. 159, $1530-1536$

29. Paul, S., Mei, S., Mody, B., Eklund, S.H., Beach, C.M., Massey, R.J., and Hamel, F. (1991) J. Biol. Chem. 266, 16128-16134

30. Gololobov, G.V., Mikhalap, S.Y., Starov, A.V., Kolesnikov, A.V., and Gabibov, A.G. (1994) Appl. Biochem. Biotech. 47, 303-315

31. Nevinsky, G.A., Kit, Y.Y., Semenov, D.V., and Buneva, V.N. (1998) Appl. Biochem. Biotechnol. 75, 77-91 
32. Ivanen, D.R., Kulminskaya, A.A., Shabalin, K.A., Isaeva-Ivanova, L.S., Ershova, N.A., Saveliev, A.N., Nevinsky, G.A., and Neustroev, K.N. (2003) Med. Sci. Monit. in press

33. Lacroix-Desmazes, S., Misra, N., Bayry, J., Villard, S., Kazatchkine, M.D., and Kaveri, S.V. (2002) J. Immunol. Methods. 269, 251-256

34. Usui, T., Murata, T., Yabuuchi, Y., and Ogawa, K. (1993) Carbohydr. Res. 250, 57-66

35. Omichi, K., Hase, S., and Ikenaka, T. (1991) J. Biochem. (Tokyo) 109, 410-415

36. Marshall, J.J., and Miwa, I. (1981) Biochim. Biophys. Acta 661, 142-147

37. Adachi, K., Suzuki, K., Ohno,Y., and Sato, B. (1986) Clin. Chim. Acta 154, 103-113

38. Jerne, N.K. (1974) Ann. Immunol. 125, 373-398

39. Gabibov, A.G., Gololobov, G.V., Makarevich, O.I., Schourov, D.V., Chernova, E.A., and Yadav, R.P. (1994) Appl. Biochem. Biotechnol. 47, 293-303

40. Tawfik, D., Chap, R., Green, B., Sela, M., and Eshhar, Z. (1995) Proc. Natl. Acad. Sci. USA 92, 2145-2149

41. Kim, K., Keller, M.A., and Heiner, D.C. (1992) Acta Paediatr. 81, 113-118

42. Gregory, R.L., Kindle, J.C., Hobbs, L.C., Filler, S.J., and Malmstrom, H.S. (1990) Oral Microbiol. Immunol. 5, 181-188

43. Eggert, F.M. and Gurner, B.W. (1984) Infect. Immun. 44, 660-664

44. Braun, C., Brayer, G.D., and Withers, S.G. (1995) J. Biol. Chem. 270, 26778-26781

45. Yu, J., Choi, S.Y., Moon, K.-D., Chung, H.-H., Youn, H.J., Jeong, S., Park, H., and Schultz, P.G. (1998) Proc. Natl. Acad. Sci. (USA) 95, 2880-2884

46. Suga, H., and Tanimoto, N. (1994) J. Am. Chem. Soc. 116, 11197-11198

Received on December 17, 2003, accepted on December 26, 2003

\section{Profile of the Authors}

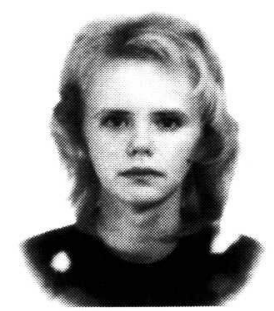

Anna Kulminskaya graduated from St. Petersburg Technological Institute in 1994 and started to work at the Petersburg Nuclear Physics Institute under supervision of Dr. Kirill Neustroev. Now she is a Researcher in the Laboratory of Enzymology and supervisor of lab's microbial collection. Her current research interests are studies of the architecture of the active center of the exo-inulinase, transglycosylation reactions catalyzed by alpha-/beta-galactosidases and catalytic antibodies with carbohydrase activities.

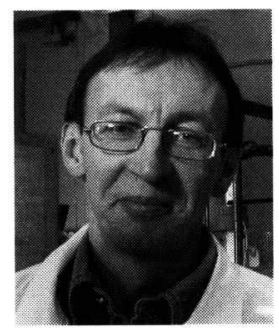

Saveliev Andrew graduated from Biophysics Department of St. Petersburg Polytechnic University and is working here since 1978 up to now days. In 1987 he received his $\mathrm{PhD}$ and began teaching at the University. The field of his scientific interest is enzymology. Andrew has two daughters and likes traveling.

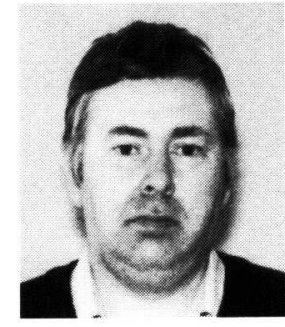

Kirill Neustroev graduated from Biophysics Department of St. Petersburg Polytechnic University in 1985 and started working at the Leningrad (now Petersburg) Nuclear Physics Institute. In 1993 he received his $\mathrm{PhD}$ and founded own research group focusing on investigations of glycoside hydrolases from microbial sources. The main research interests are carbohydrate-modified enzymes, transglycosylation, dehydrogenases and catalytic antibodies. 